\title{
Docência na prisão: relação professor-aluno e identidade docente
}

\author{
Teaching in prison: teacher-student relationship and teaching identity \\ Docencia en la prisión: relación profesor-alumno e identidad docente \\ Alisson José Oliveira Duarte* \\ HELENA DE ORNELLAS SIVIERI-PEREIRA**
}

\begin{abstract}
RESUMO
O presente estudo busca descrever como a relação do professor com seus alunos, em situação de privação de liberdade, pode influenciar na maneira pela qual o docente constitui sua autoimagem, autoestima e realização profissional. A pesquisa contou com a participação voluntária de cinco professores da educação escolar de uma instituição prisional e com uma entrevista com a diretora da escola. Para tanto, foram utilizados como instrumentos de coleta de dados entrevistas abertas e registro em diário de campo. Os resultados sugerem que a relação professor-aluno representa um elemento significativo no processo de constituição da identidade profissional dos docentes da unidade prisional pesquisada.
\end{abstract}

Palavras-chave: Docência na prisão. Identidade docente. Relação professor-aluno.

\begin{abstract}
In this article, we sought to describe how the teacher's direct relationship with his students in deprivation of liberty can influence the way in which the teacher constitutes his self-image, self-esteem and professional fulfillment. The investigation included the voluntary participation of five teachers from the school education of a correctional institution and an interview with the director of the school. For this purpose, data collection instruments were used: open interviews and field diary records. The results suggest that the teacher-student relationship represents a significant element in the process of constitution of the professional identity of the teachers of the penitentiary unit investigated.
\end{abstract}

Keywords: Teaching in prison. Teaching identity. Teacher-student relationship.

\section{RESUMEN}

En el presente artículo se buscó describir cómo la relación directa del profesor con sus alumnos en privación de libertad puede influenciar en la manera en que el profesor constituye su autoimagen, autoestima y realización profesional. La investigación contó con la participación voluntaria de cinco profesores de la educación escolar de una institución penitenciaria y una entrevista con la directora de la escuela. Para ello se utilizó como instrumentos de recolección de datos: entrevistas abiertas y registros en diario de campo. Los resultados sugieren que la relación profesor-alumno representa un elemento significativo en el proceso de constitución de la identidad profesional de los profesores de la unidad prisional investigada.

Palabras clave: Docencia en la cárcel. Identidad docente. Relación profesor-alumno.

\footnotetext{
*Universidade Federal do Triângulo Mineiro - UFTM. Mestre em Educação pela Universidade Federal do Triângulo Mineiro. Especialista em Psicanálise Clínica.<https://orcid.org/0000-0002-1390-4979>. E-mail:<alisson-duarte@hotmail.com>.

**Doutora em Psicologia pela FFCLRP-USP (2008), mestre em Psicologia Escolar pela Pontifícia Universidade Católica de Campinas (1999). Professora adjunta da Universidade Federal do Triângulo Mineiro (UFTM). Docente permanente do Programa de Pós-Graduação em Educação (Mestrado em Educação).<https://orcid.org/0000-0003-3694-2705>. E-mail: <helena.sivieri@gmail.com>.
} 


\section{INTRODUÇÃO}

Historicamente, a primeira instituição prisional brasileira, a Casa de Correção da Corte, foi fundada no Rio de Janeiro, em 1834, durante o reinado de Dom Pedro II. Desde a fundação, há registros históricos de um modelo educacional prescrito em seus regulamentos. De acordo com Vasquez (2008), o cargo do professor, no período imperial, era executado pelo capelão. Sua função era zelar pela educação moral e religiosa dos presos. Posteriormente, a educação escolar das populações cativas sofreu significativas mudanças no governo de Juscelino Kubitschek (1956-1961), no período do Regime Militar (1964-1985), na promulgação da Constituição de 1988 e, por último, nas novas revisões que têm sido feitas no início do atual século (DUARTE; SIVIERI-PEREIRA, 2018).

Sabe-se que o direito à educação escolar é legítimo a partir de previsões legais estabelecidas tanto em planos nacionais como internacionais. No plano internacional, de acordo com Oliveira (2013), destaca-se a Declaração Universal dos Direitos Humanos, que, no artigo 26, estabelece a educação como um direito de todas as pessoas independentemente de qualquer condição. |No plano nacional, o direito universal à educação é consolidado a partir da promulgação da Constituição Federal de 1988, conforme se lê em seu artigo 205: "A educação, direito de todos e dever do Estado e da família, será promovida e incentivada com a colaboração da sociedade, visando o pleno desenvolvimento da pessoa, seu preparo para o exercício da cidadania e sua qualificação para o trabalho" (BRASIL, 1988). A educação escolar na prisão integra a modalidade de ensino intitulada Educação de Jovens e Adultos (EJA), sendo, portanto, regida nesses espaços pelas normativas nacionais estabelecidas para essa modalidade de ensino.

Cabe ressaltar que trabalhar e estudar confere à pessoa em privação de liberdade o direito de remição de pena, isto é, de abreviar reprimida imposta pela sentença penal mediante o exercício formal e institucionalizado dessas atividades. Esse direito é previsto na Lei $\mathrm{n}^{\mathrm{o}}$ 7.210/84 de Execução Penal e estabelece, para cada três dias trabalhados, a remição de um dia de pena e, para cada doze horas de frequência escolar, menos um dia de pena; geralmente, as aulas têm duração de três horas, sendo necessários quatro dias de aula para se debitar um dia de pena (BRASIL, 1984).

Embora a educação escolar nos presídios não seja fato recente na história do país, esta ainda é, de acordo com Onofre (2011), um dos campos mais negligenciados e marginalizados pelas políticas públicas e pela própria educação, principalmente no que se refere à pessoa do professor. Nesse sentido, a presente pesquisa justificase pela necessidade de fomentar estudos que ofereçam suporte teórico e reflexivo em torno da educação escolar ministrada nas instituições prisionais e, sobretudo, em relação à constituição da identidade de professores que atuam nessa área específica da realidade educacional.

Busca-se com este estudo descrever como a relação do professor com seus alunos em privação de liberdade pode influenciar na maneira pela qual o docente constitui sua autoimagem, sua autoestima e sua realização profissional. Para tanto, com base nos preceitos éticos e no respeito à dignidade humana, - instaurados pela Resolução CNS $\mathrm{n}$ - 466, de 12 de dezembro de 2012, que define as diretrizes da pesquisa com seres humanos -, elege-se uma escola instituída em uma unidade prisional do interior de Minas Gerais como campo de investigação, e os professores(as) que atuam em seu âmbito, como sujeitos desta pesquisa (DUARTE, 2017).

A opção metodológica para o desenvolvimento deste estudo apoia-se no modelo qualitativo, utilizando-se de investigações em campo e levantamento de referenciais teóricos para alcançar os objetivos propostos. Utilizam-se, como instrumentos de coleta de dados, entrevistas abertas e registro em diário de campo. A pesquisa contou com a participação voluntária de cinco professores da educação escolar da instituição prisional pesquisada e com uma entrevista de caráter complementar com a diretora da escola. Todos os participantes leram, concordaram e assinaram o Termo de Consentimento Livre e Esclarecido (TCLE). Para manter o caráter ético desta pesquisa, os verdadeiros nomes dos entrevistados foram mantidos em sigilo e devidamente substituídos por pseudônimos, conforme o Quadro 1.

Quadro 1. Caracterização dos sujeitos

\begin{tabular}{|l|c|l|c|}
\hline Pseudônimo & Idade & Formação & $\begin{array}{c}\text { Tempo de docência para alunos } \\
\text { em privação de liberdade }\end{array}$ \\
\hline Josefina & 59 anos & Licenciatura em Letras & 9 anos \\
\hline Ariane & 35 anos & Ciências Biológicas & 4 anos \\
\hline Thiago & 35 anos & Licenciatura em Letras & 3 anos \\
\hline Antônia & 58 anos & Licenciatura em Letras & 6 anos \\
\hline Letícia & 40 anos & Lic. em Ciências Sociais & 5 anos \\
\hline
\end{tabular}

Fonte: Os autores (2018) 
Todos os professores entrevistados, além de ministrarem aulas no interior da instituição prisional em foco, também mantinham (até o momento da coleta de dados) vínculo com outras escolas da rede pública do município mineiro sede da referida instituição prisional. Salienta-se que a diretora da escola não entrou no quadro de caracterização dos sujeitos por não pertencer diretamente à amostragem de sujeitos docentes; encontram-se, em seus relatos, informações complementares sobre a docência em instituições prisionais, mas não há fonte para uma possível análise do processo de constituição da identidade docente em espaços de cerceamento de liberdade.

Tratando-se de um estudo voltado para a compreensão da identidade de docentes da educação escolar de uma instituição prisional, era importante que eles tivessem pelo menos um ano de experiência no referido campo, com condições de expressar conhecimentos vivenciais, consolidados e relevantes para a pesquisa. Também era considerado fundamental que os docentes já tivessem experiência profissional com alunos socialmente livres. Embora a escola contasse com dezesseis professores, apenas cinco deles preencheram os critérios mínimos estabelecidos para participarem da pesquisa.

Os professores foram contatados dentro da própria instituição prisional, com autorização do diretor do presídio e da diretora da escola. Posteriormente, foram entrevistados em horário e local previamente agendado. As entrevistas foram audiogravadas e redigidas com fidelidade, assim como foram recolhidas da fonte.

A maioria dos professores entrevistados iniciaram suas atividades docentes na escola da unidade prisional depois de serem indicados por outros docentes que já exerciam atividades laborais nessa instituição. Atualmente, sabese que existe um processo de designação formalizado e publicado em edital no site da Superintendência Regional de Ensino do Estado de Minas Gerais.

Nessa unidade prisional, todos os professores ministram aulas do ensino fundamental ao médio. As turmas são heterogêneas, contendo adultos de diferentes idades, e são abertas conforme a necessidade para preencher a quantidade mínima de cinco alunos. Há uma variação média de dois a oito alunos por sala de aula, não ultrapassando doze alunos por turma. O regime das aulas é diário, de segunda a sexta-feira e cada aula tem duração de quarenta minutos, sem intervalo, totalizando três horas de aula por dia (Diário de Campo).

A unidade prisional, inaugurada no ano de 2006, foi construída para comportar cerca de 690 pessoas em privação de liberdade, no entanto, geralmente o número de pessoas institucionalizadas oscila entre 1.300 a 1.600 pessoas (entre homens e mulheres). Desse total oscilativo, uma pequena parcela, igualmente variável, é matriculada na escola (Diário de Campo).
Os sujeitos da pesquisa (professores da educação escolar da referida instituição prisional) lecionam no interior de salas de aula estrategicamente instituídas ao longo dos pavilhões. No total, a unidade prisional pesquisada dispõe de dezesseis salas de aula espalhadas em cinco pavilhões (Fechado I, Fechado II, Fechado III, Semiaberto e "Vivência Feminina"). ${ }^{1}$ As aulas acontecem em dois turnos, matutino e vespertino. Os professores são encaminhados para dentro das salas de aula pelos agentes penitenciários, que em seguida os deixam trancados (sozinhos e sem qualquer guarnição) com as pessoas em privação de liberdade até o término da aula (Diário de Campo).

As salas de aula possuem aproximadamente $3,5 \mathrm{~m} \times$ 4,0 $\mathrm{m}$ de dimensão, dispondo de uma saída de ventilação no formato de tela de aço reforçado e banheiro (com vaso sanitário, pia e torneira). Via de regra, em todas as salas de aula, os banheiros não possuem portas. A instalação comporta aproximadamente doze assentos para os alunos (ou carteiras escolares), uma mesa com cadeira para o professor e um quadro de giz de cor preta de aproximadamente $1,5 \mathrm{~m} \times 2 \mathrm{~m}$ de comprimento. A saída da sala é um portão de grades vazadas (em aço maciço), munido com trancas de alta segurança (Diário de Campo).

Os alunos em privação de liberdade, às vezes, são encaminhados com uma hora de antecedência de suas celas de convivência para o interior das salas de aula pelos agentes penitenciários, onde fazem o desjejum ou almoçam e aguardam o professor. Chegam algemados, mas suas algemas são retiradas quando já estão acomodados no interior da sala. As aulas não possuem intervalo. Depois que o professor se retira do ambiente, os alunos passam por minucioso processo de revista e são novamente encaminhados para suas celas (Diário de Campo).

Fora das salas de aula, os professores também dispõem de uma biblioteca e de uma secretaria, onde se reúnem e mantêm contato com a diretoria.

Por meio dos resultados alcançados, observa-se que a relação professor-aluno representa um elemento significativo no processo de constituição da identidade profissional dos professores da unidade prisional pesquisada.

\footnotetext{
${ }^{1} \mathrm{O}$ termo "Fechado" refere-se aos pavilhões nos quais convivem, sobretudo, homens em privação de liberdade que receberam condenação e já se encontram em cumprimento oficial de sua pena. "Semiaberto" diz respeito ao pavilhão onde convivem as pessoas em privação de liberdade que adquiriram o direito judicial (isto, é progressão de regime) para trabalharem durante o dia fora da instituição prisional, devendo retornar em horário exato para esta depois do cumprimento de suas atividades laborais. Por outro lado, o termo "Vivência Feminina", ou em sua forma reduzida "Vivência", faz parte do vocabulário local dessa instituição, utilizado para designar o pavilhão onde convivem as mulheres em privação de liberdade, condenadas ou não (Diário de Campo).
} 


\section{RELAÇÃO PROFESSOR-ALUNO}

Durante a coleta de dados da pesquisa, constatou-se que foi unânime entre os professores declarações que ressaltavam, de maneira positiva, a relação entre professores e alunos. Em alguns casos, expressando espontaneamente uma nítida preferência pela docência em espaços de privação de liberdade em comparação à docência em ambientes escolares não instituídos em unidades prisionais. Por meio da análise dos dados, entende-se que a relação professor-aluno, marcada pela simpatia, respeito mútuo e aceitação incondicional, confere aos docentes sentimentos de satisfação em relação à docência e sobre si mesmos enquanto profissionais.

De acordo com Bolívar (2006), o grau de satisfação profissional, bem como a maneira que os professores concebem a sua autoimagem estão entre os principais componentes psicológicos e sociológicos que configuram e marcam a constituição da identidade docente.

Nesse sentido, busca-se, na presente pesquisa, descrever como as características marcantes da relação professor-aluno, tais como afetividade, respeito, interesse pelas aulas e valorização do professor, estão estreitamente ligadas ao sentimento de (a) realização profissional e (b) autoimagem e autoestima que constituem a identidade profissional dos docentes pesquisados.

\section{SENTIMENTO DE REALIZAÇÃo PROFISSIONAL}

Ressalta-se que todos os professores entrevistados revelaram, em seus discursos, sentimentos positivos em relação à sua realização profissional enquanto docentes de alunos em privação de liberdade. Esse sentimento de completude foi justificado pelos docentes entrevistados em torno de cinco argumentos intensamente frisados pela maioria deles: afetividade do aluno em relação ao professor; respeito ao seu trabalho, bem como a sua presença em sala de aula; maior interesse pelas aulas em comparação aos alunos de sua experiência fora da unidade prisional; valorização incondicional da pessoa do professor; e menor quantidade de alunos por sala de aula.

De acordo com Bolívar (2006), a avaliação (o juízo positivo ou negativo) que o indivíduo tem diante de suas experiências profissionais está estreitamente ligada às respostas afetivas ou emocionais em relação à sua própria identidade. Ele ressalta ainda que "os alunos evidentemente são aqueles que proporcionam feedback e satisfação ao trabalho" docente (2006, p. 146, tradução dos autores). O retorno positivo do aluno (interesse pelas aulas, aprendizagem e valorização da pessoa do professor), segundo o autor, confere aos docentes recompensas psíquicas e emocionais importantes para a constituição de uma identidade intrinsecamente realizada.

Em entrevista, o professor Thiago relatou os motivos de sua satisfação em ministrar aulas para alunos em privação de liberdade:

\begin{abstract}
"Eu me apaixonei pela educação no sistema prisional. Hoje em dia, como professor fora do sistema prisional, eu falo que a comparação não tem nem como ser feita, porque dentro do sistema você é valorizado, você é respeitado, sua aula flui; então tudo que você preparou você consegue executar, enquanto, aqui fora, principalmente com jovens, é algo praticamente impossível, porque essa questão do respeito do aluno de entender qual o papel da escola na vida deles se torna muito complicada." (Thiago)
\end{abstract}

Em determinados momentos da entrevista, Thiago chegou a expressar que os alunos têm uma "supervalorização" em relação à pessoa do professor, e que esse sentimento é uma das razões pelas quais se sentia motivado a continuar lecionando na escola da unidade prisional.

Encontram-se nas afirmações da professora Ariane relatos muito semelhantes aos do professor Thiago. De maneira geral, a professora parece sintetizar a concepção geral de que os professores se sentem realizados atuando na educação de alunos em privação de liberdade devido aos cinco fatores já mencionados (valorização, respeito, interesse, afetividade e menor quantidade de alunos por sala de aula):

\begin{abstract}
"Na Educação de Jovens e Adultos do sistema prisional, você trabalha com alunos que vão lá e estão interessados em assistir à aula. Você não precisa chamar a atenção deles, eles mesmos sabem a hora que eles têm de ouvir e falar. Lá você vê o resultado real de seu trabalho, lá você realmente consegue dar aula, você explica para quem está te ouvindo. Mesmo diante de certas situações que ocorrem, de certos obstáculos, a gente se sente realizada, porque a partir do momento que eu entro na sala de aula, nem que seja 15, 20 minutos, mas são 15, 20 minutos de aula dada, produtiva e a gente tem certeza de que alguma coisa eles aprenderam com aquela aula, e aqui fora a gente não tem esse mesmo valor." (Ariane)
\end{abstract}

Josefina afirmou que sempre obteve de seus alunos muito respeito em relação à sua pessoa e à sua presença. Durante a entrevista, relatou com satisfação:

“(...) eles me tratam muito bem, com muito carinho, sabe, com muito respeito, muito mesmo. Por exemplo, um dia eu estava lá no pavilhão e dois presos de uma cela começaram a brigar e um deles xingou o outro com um palavrão. Então, um aluno da sala de aula chegou na grade e gritou: 'Oh, respeita que aqui tem 
professora, por favor, vocês maneirem, porque aqui tem professora'. Exatamente, um aluno da sala de aula chamou a atenção do outro que estava dentro de uma cela. Porque a gente trabalha dentro do pavilhão, então escutamos tudo." (Josefina)

Quando a mesma foi questionada se gostava de ser professora de alunos em situação de privação de liberdade, respondeu com veemência: "Ah, eu gosto! Lógico, eu gosto". Em seguida, percebeu-se em seu discurso que um dos motivos de sua satisfação em ministrar aulas na escola da unidade prisional em parte estava relacionado ao interesse do aluno no conteúdo ministrado e/ou a sua dedicação em relação à escola, conforme o relato:

\begin{abstract}
"Eu acho interessante porque eu olho para eles e penso 'engraçado, tão moços, alguns mais velhos do que os alunos da rua' e se você vê que gracinha os cadernos, que bonitinho, tem uns que desenham. Dentro da unidade prisional, a gente vê os cadernos tão bem feitinhos, caprichados. Então eu admiro aquilo, fico observando, eles querem caprichar na letra, põem peso sobre o caderno para não dar orelha (...). Eles são muito dedicados. Não gostam de tirar nota ruim." (Josefina)
\end{abstract}

De acordo com Onofre (2012, p.211), o possível mal-estar docente inspirado pela estrutura da instituição prisional é rapidamente superado e se torna "fonte de bem-estar docente, pelo reconhecimento de seu valor para os alunos, pelo respeito e pela confiança na figura do professor, despertando motivações intrínsecas pertinentes à carreira, como o gosto de ser professor e a realização profissional".

A apuração dos dados revelou que os professores entrevistados também apontavam nos relatos um sentimento de aceitação incondicional no que diz respeito aos seus alunos em situação de privação de liberdade, mostrando satisfação, carinho e cuidado em relação a eles:

"Eu me preocupo com eles. Eu pergunto para o colega: 'Por que o fulano sumiu? Por que ele não está vindo?'. 'Ah, ele está com depressão, ah porque ele está tomando muito remédio'. Então a gente se preocupa com eles também (...). Eles dizem que não devem criar vínculo, não pode. Mas, quer queira, quer não queira, cria uma ligação. Não tem como você não querer saber o que ele tem, o que ele está sentindo, se ele está com uma dor, se ele está passando mal, a gente se preocupa." (Josefina).

Ainda sobre o sentimento de aceitação incondicional do professor para com os seus alunos, uma das entrevistadas, a professora Ariane, menciona suas concepções:
Em meu ponto de vista, eu não posso olhá-lo como um preso, ele é meu aluno... Ali dentro ele não é um Infopen $^{2}$, não se fala do que ele cometeu, às vezes a gente sabe porque alguns sentem a necessidade de falar (...). O espaço é dividido somente por uma grade, que separa a cela deles com a sala de aula. Mas a partir do momento que ele é inserido dentro da sala de aula, ali ele se sente à vontade para falar e expressar opiniões, porque a escola dá esse espaço para eles. Depois que eles passam da grade para lá, eles não podem se expressar, eles não são ouvidos, eles são sempre errados." (Ariane)

Tendo em vista o histórico criminal de alguns dos alunos em privação de liberdade, que naturalmente em uma unidade prisional podem ter sido autores de ações criminosas das mais variadas categorias, como homicídios, latrocínios, assaltos à mão armada, tortura, estupro e outras modalidades de ações violentas, investigou-se entre os professores se eles se sentiam ansiosos ou intimidados com a presença de seus alunos. Todos, diferentemente do que em geral povoa o imaginário geral, afirmaram com muita segurança manter uma relação muito tranquila e sem qualquer tensão. Aliás, muitos dos entrevistados relataram inclusive uma relação de muita proximidade com seus alunos, independentemente do(s) crime(s) que tenham cometido.

\begin{abstract}
"De forma nenhuma me sinto ansiosa com eles. Sinto-me assim, sabe... a gente nem pode dizer isso, mas eu me sinto como se tivesse conversando com um colega." (Josefina).

"Eles me deixam super à vontade. Eles tratam a gente com respeito, tem até um certo... a gente sente que eles têm um certo carinho com a gente. Quando eles pegam confiança na gente, eles falam da vida deles, porque estamos lá dentro, não adianta, você se torna professor, psicólogo." (Ariane).
\end{abstract}

Todos os entrevistados negaram qualquer situação conflituosa mais intensa com os alunos ou a existência de algum tipo de ameaça. Quando arguida se alguma vez teria sofrido intimidação vinda de seus alunos, Ariane negou com veemência:

\begin{abstract}
"Nunca sofri ameaças. Aliás, uma vez, um aluno falou para mim: 'Professora, na casa da senhora, nas coisas da senhora, ninguém mexe, mas se mexerem, fale para nós, porque a gente vai atrás e dá um jeito'. Eles acabam tendo a missão de proteger o professor. Eles perguntam se os agentes faltam com o respeito com a gente, porque não pode faltar com respeito com a gente." (Ariane)
\end{abstract}

\footnotetext{
${ }^{2}$ Infopen (Levantamento Nacional de Informações Penitenciárias) refere-se a uma sequência numérica com a qual se identifica em um banco de dados informações de qualquer pessoa brasileira que tenha sido submetida a um processo de privação de liberdade.
} 
Josefina ressalta que os alunos valorizam muito os professores e demonstra pela maioria deles muita afetividade. Conforme seu relato, observa-se que a prática docente possivelmente confere a ela satisfação profissional e pessoal:

\begin{abstract}
"O que me faz permanecer (na educação para alunos em privação de liberdade) não é somente a necessidade financeira, mas essa questão da afetividade, pois o retorno lá é muito grande. Você vê a satisfação deles por você estar ali junto deles: 'Nossa, professora, já acabou a aula da senhora? Nossa, passa tão rápido'. Aquilo é muito bom. (...) A gente se sente valorizada porque, por exemplo, eu, na minha profissão, eu estou com 59 anos, aqui fora poderiam dizer: 'Essa aí é uma velha'. Agora, lá não, imagina que eles falam isso pra gente. Ah, se você falar que vai sair, eles acham muito ruim. Saiu uma professora de lá: 'Nossa, aquela professora foi embora, que pena'. Tem professoras que já saíram de lá há muito tempo e eles lembram até hoje. (...) Então o reconhecimento lá é muito grande, a afetividade deles é muito grande com a gente. Eles vão tomar café, eles te oferecem, eles vão almoçar, te perguntam: "A senhora aceita, a senhora quer?". Levam, por exemplo, um bolo, uma coisa assim dentro do saquinho: 'A senhora quer comer com a gente? A senhora quer?'. Às vezes, eles largam de comer um doce e querem que você coma o doce deles." (Josefina).
\end{abstract}

Bolívar (2006, p. 145, tradução dos autores) sugere que "o aluno constitui o principal agente de satisfação do professorado", ressaltando que o interesse pelas aulas demonstrado pelos alunos e o reconhecimento do esforço do professor em relação à preparação das aulas estão entre as principais e melhores recompensas que podem ser recebidas na profissão docente.

Ariana e Antônia acreditam que ministrar aulas para alunos em privação de liberdade seja uma tarefa consideravelmente menos desgastante do que ministrar aulas para alunos não privados de liberdade. Isso porque, segundo elas, alunos em condição de cerceamento de liberdade, além de adultos, também se encontram em uma posição de subordinação e submissão ao sistema:

"Eu acho que tem a ver com a situação pela qual eles estão vivendo, a partir do momento que ele entra ali dentro da penitenciária, que ele veste aquele uniforme vermelho, ele acaba perdendo um pouco de sua identidade. Ele tem que se adaptar àquele local (...). Ou ele se adapta, ou ele sofre consequências, e ele não quer, ele quer ir embora o mais rápido possível." (Ariane)

"Parece que não, mas eu acho mais fácil lidar com alunos em privação de liberdade do que com os adolescentes aqui fora. Lá dentro eles têm regras, senão eles têm castigo, comunicado, ainda mais aqueles que estão prestes a ir embora, eles têm certo receio." (Antônia)
Josefina, por sua vez, ressalta que a vinculação positiva do aluno ao professor se deve a uma espécie de carência afetiva, pois muitos não tiveram pais ou familiares presentes na infância e por essa razão projetam sentimentos maternais/paternais sobre os professores:

\begin{abstract}
"Eles são muito carentes porque muitos ali não tiveram uma mãe ou a maioria das mães eram alcoólatras, drogadas, etc. Então não tiveram esse afeto. Então eu acho que eles se apegam muito à gente por isso. Às vezes, acontecem situações que a gente conversa e vai notando essa grande defasagem emocional. Um aluno, por exemplo, me falou: 'Dona Josefina, minha mãe nunca comprou um lápis para mim, minha mãe nunca sentou comigo e fez uma tarefa. Minha mãe nunca foi à escola nem me ver dançar quadrilha'. Eu acho que essa carência é o que faz eles se apegarem aos professores. Porque somos muito carinhosas com eles." (Josefina)
\end{abstract}

Outro ponto ressaltado pelos professores, com o qual se destacam o prazer e a realização profissional dos entrevistados, diz respeito à quantidade de alunos por sala de aula em relação à quantidade de alunos comumente observada nas escolas não instituídas em unidades prisionais. $\mathrm{O}$ fato provavelmente justifica-se pela praticidade pedagógica para administrar uma turma menor, com menos desgaste físico, com mais qualidade e proximidade dos alunos. Nesse sentido, a maioria dos professores afirmou não ultrapassar doze alunos, havendo uma variação média de dois a oito alunos por sala de aula. Assim como é possível constatar-se nas considerações do professor Thiago:

“Às vezes, no início do ano, o professor pega uma turma grande, mas vai finalizar com oito, cinco. Eu já tive turmas com dois alunos. Esse número reduzido de alunos nos permite produzir uma aula bem mais fácil, acompanhando-os mais de perto. Enquanto fora da unidade prisional tenho turmas de 34; a menor tem 27 alunos." (Thiago)

Ariane justifica que a qualidade da relação entre professores e alunos se deve à sua proximidade, raramente observada entre as pessoas em privação de liberdade e em outras categorias profissionais que atuam na unidade prisional. De acordo com a interlocutora, todos os profissionais da unidade prisional estão "ali para ajudá-los" e são respeitados pelas pessoas em privação de liberdade, mas, conforme a sua concepção, a relação do professor com os alunos destaca-se pela proximidade física e emocional: (...) "temos um contato direto com eles, diário e frequente, porque a gente fica dentro de uma mesma sala, trancado com eles, então eu às vezes me sento com um preso ao meu lado". Segundo a entrevistada, esse contato diferencia-se qualitativamente da relação dos assistentes sociais, psicólogos e enfermeiros, que 
recebem a pessoa em privação de liberdade dentro de uma sala separada nas dependências do núcleo de saúde, algemados e fora dos pavilhões de convívio coletivo.

“(...) eu acho que o diferencial do professor é estar dentro da sala com ele. Ele vê que o professor não é resistente, que ele não foi lá com aquele tanto de segurança ${ }^{3} \ldots$ isso passa para eles que eles estão oferecendo risco para aquela pessoa... já o professor fica sozinho com o preso, o agente penitenciário "tchau", e aí a gente tem um contato muito próximo com eles, a gente acaba criando com eles um vínculo." (Ariane)

$\mathrm{Na}$ unidade prisional, as grades, as algemas, os cadeados, as muralhas separam o mundo dos livres e dos presos, o mundo das pessoas consideradas dignas e a sociedade dos vilões, o mundo das pessoas de bem e o mundo das pessoas consideradas perigosas. Mesmo que não seja diretamente declarado, parece haver uma rivalidade entre os dois universos, isto é, daqueles que transitam pela unidade prisional sem algemas e aqueles que são conduzidos algemados e trajados de uniforme vermelho (DIÁRIO DE CAMPO). As afirmações da professora Ariane são sugestivas de que os professores, ao adentrarem no mundo do cárcere desprotegido de grades, algemas e agentes penitenciários, igualam-se aos presos (no sentido de estarem trancados). Isto é, não havendo barreiras de proteção, também se encontram simbolicamente despojados de valores e preconceitos. Josefina, nessa mesma linha de reflexão, em dado momento da entrevista, afirmou que um aluno disse a ela: "A senhora é presa igual a nós, só que você vem da rua trabalhar aqui", fato que ela confirmou:

\begin{abstract}
“"Eu sou o oposto, eu passo o dia aqui e vou para casa dormir. Então é ao contrário nossa vida. Meu semiaberto é diferente do de vocês.' Isso porque a gente fica sozinha com eles, o tempo todo presa lá dentro." (Josefina)
\end{abstract}

Ao mesmo tempo, a fala dos entrevistados sugere que, além de os professores diferenciarem-se no universo dessa unidade prisional por adentrarem nas "celas de aula", parece haver entre eles um sentimento geral de reconhecimento da gratidão dos alunos em relação às possíveis dificuldades de se ministrar aulas em escolas das unidades prisionais. Como se a docência nesses locais fosse um sacrifício na concepção dos alunos:

\footnotetext{
${ }^{3}$ A entrevistada, ao usar o termo segurança, refere-se aos agentes penitenciários que permanecem em pé do lado de fora das salas de atendimento de assistentes sociais, médicos, enfermeiros, psicólogos e advogados quando as pessoas em privação de liberdade são trazidas dos pavilhões para as salas de atendimento no núcleo de atenção à saúde.
}

\begin{abstract}
"Eles falam 'tantas escolas para o professor trabalhar, o professor vem aqui, passar por revista, passar por essas enjoeiras todas, trabalhar com esse barulho e tal', eles veem o que a gente enfrenta para poder ir lá ministrar aulas para eles, então eles veem que a gente não tem preconceito com eles, que se a gente tivesse um preconceito, a gente não estava lá dentro. Então ele tem uma visão da gente como uma pessoa que está ali para fazer o bem para eles." (Ariane)
\end{abstract}

A percepção de que os alunos veem a docência nos presídios como uma condição de sacrifício por parte dos professores também foi evidenciada quando muitos deles relataram que, ao iniciarem suas atividades na escola da unidade prisional, eram frequentemente arguidos pelos alunos em privação de liberdade se sentiam medo de estarem na companhia deles; se não tinham a oportunidade de trabalhar em outra escola e o porquê de estarem atuando em uma escola de unidade prisional.

\section{Autoimagem e Sentimento DE AUTOESTIMA}

As análises dos dados revelaram que os professores entrevistados frequentemente associam a sua identidade profissional à função de "conselheiros" por atenderem demandas emocionais; "missionários", devido ao sentimento de que podem contribuir para a transformação da conduta dos alunos; e "corajosos", por desempenharem um trabalho considerado desafiante segundo o imaginário social. Essas percepções sugerem que os professores conservam em relação a si mesmos um sentimento positivo de autoestima enquanto professores de alunos em privação de liberdade.

Bolívar (2006, p. 40, tradução dos autores) afirma que a identidade profissional é ao mesmo tempo a experiência pessoal, o papel socialmente reconhecido, a experiência subjetiva dos sujeitos e a maneira pela qual os outros veem o indivíduo. Ele constrói sua identidade pelo olhar do outro, isto é, "nenhuma pessoa pode construir sua identidade à margem das identificações que os outros formulam sobre ela".

Ciampa (1997) concebe identidade como contraditória e mutável, mas ao mesmo tempo una, caracterizando-se por um "vir a ser" sempre inacabado. A partir desse ponto de vista, diferença e igualdade surgem como a base desse conceito, compreendidas pelo movimento do igualar-se e do diferenciar-se, dependendo dos diversos grupos que, ao longo da vida, o indivíduo vai fazendo parte. Para o autor, a pessoa é uma totalidade, e a profissão é tão somente a manifestação de uma parte da unidade. A identidade tem caráter dinâmico e pode ser vista como o resultado provisório da intersecção entre a história da pessoa, de seu contexto histórico, social e de suas particularidades. 
Rogers (2001) salienta a necessidade da empatia e da autenticidade como pilares para uma relação humana congruente, isto é, livre de máscaras e genuinamente sincera. Nesse tipo de relação, professores e alunos têm a liberdade de se expressar, sem censura ou condições, de modo que ambas as partes tenham condições de identificar pelas emoções do outro as ressonâncias e os limites de seu próprio "eu".

Bolívar (2006) ainda ressalta que as necessidades do aluno, bem como o seu feedback, situam os professores perante a importância de seu papel enquanto docente e representam (ou comunicam) a qualidade de seu desempenho profissional. O comportamento do aluno confere, ao mesmo tempo, a motivação profissional para o trabalho docente, o autorreconhecimento e a fonte de autoestima profissional. Logo, a autoimagem do professor é mediada pelas especificidades do contexto (lócus de sua práxis) e das necessidades de seus alunos.

Constatou-se, por meio dos entrevistados, que professores da educação escolar da unidade prisional pesquisada têm de lidar com aspectos da labilidade emocional de seus alunos, muitas vezes não sendo possível dar sequência ao plano de aula sem efetuar intervenções que amenizem o seu sofrimento psicológico (não raras vezes, de mais de um aluno ao mesmo tempo).

Sivieri-Pereira (2008, p. 130-131), em seus estudos acerca dos reflexos das dimensões pessoais do professor em sua vida profissional, afirma que frequentemente as relações que os professores estabelecem com seus alunos não ficam impassíveis à vida pessoal dos mesmos, de modo que muitas vezes buscam "ajudá-los no que podem, inclusive em situações alheias ao trabalho na escola". Isso porque é difícil separar a relação professoraluno de suas dimensões pessoais. Para a autora, não raras vezes o professor se atém à "formação global" do aluno, preocupando-se com aspectos que vão além dos conteúdos acadêmicos.

A esse respeito, Josefina relatou como procede quando identifica que um aluno não está emocionalmente bem:

\begin{abstract}
“(...) geralmente, quando eu vejo que um aluno da turma não está legal, eu falo pros meninos continuarem a atividade que eles estiverem fazendo e vou lá e me sento do lado do aluno e converso. Aí eu deixo ele falar o que quiser, o que está sentindo: 'Estou angustiado, estou com problema assim, minha família está passando falta das coisas'. Eu deixo ele se abrir e dou minha opinião no que eu posso ajudar (...) Esse trabalho que a gente tem, de poder orientar, de poder ajudar, é muito gratificante." (Josefina)
\end{abstract}

Observa-se na fala da última professora que, além da necessidade de os alunos receberem apoio emocional, o professor se sente realizado ao ajudá-los. A professora
Letícia, referindo-se a um período de experiência como docente no pavilhão feminino, relata:

\begin{abstract}
"Eu entrava na sala e comigo era frequente, elas já vinham chorando e eu falava: 'Como assim, o que aconteceu?'. Aí não adianta falar 'copia aqui e pronto', ali não tem como ser mecânico, é preciso fazer alguma coisa, pois eles são muito fragilizados. Eu não sei o que cada um cometeu, não me cabe saber. Eles sempre trazem problemas de uma forma geral e eu os acolho. Ao final da aula, agradecem: 'Que bom ter conversado comigo, tirou um peso de meu coração'.” (Letícia)
\end{abstract}

É interessante ressaltar na fala da última entrevistada que a sua relação com o aluno é marcada pela aceitação incondicional do discente, uma vez que o apoio emocional oferecido a ele independe do conhecimento acerca do crime que tenha cometido. Nesse sentido, identificouse na fala da professora que sua atuação profissional é realizada desprovida de qualquer preconceito que faça referência às atitudes passadas de seus alunos.

Levando em consideração as perspectivas teóricas da Psicologia Humanista de Rogers (2001), entende-se que a aceitação incondicional do aluno faz da escola um espaço afetuoso e de compreensão, tornado-a um ambiente facilitador de aprendizagens e possibilitando ao aluno condições de aprender e expressar-se sem julgamentos. Assim como deve ser em qualquer espaço que se destine ao processo de ensino-aprendizagem.

Em relação à condição emocional dos alunos de um modo geral, o professor Thiago expõe:
"O emocional deles fica muito abalado. Às vezes, tem um dia de visita, tem dia que acontece alguma coisa lá entre eles, tem dias que eles chegam e falam: 'Professor, hoje eu não estou bem, eu vou ficar quietinho aqui'. Às vezes eles pedem para ficar na sala de aula só para olhar pela grade... E eu sempre tento respeitar, já que ele está o ano todo ali fazendo tudo, e no dia em que ele não está bem, eu acho que não devo forçar." (Thiago).

A diretora da escola, mesmo não vivenciando diretamente a realidade no interior das salas de aula, afirma que, no dia em que o aluno não está psicologicamente bem, faz-se necessário que o professor atue de modo a "resgatar o ser humano", isto é, acolhendo o seu lado emocional. Ressalta, porém, que não é conveniente que se façam tais intervenções "o tempo todo".

Onofre (2015) considera que a educação escolar em unidades prisionais ainda precisa passar por inúmeras reformas que garantam o seu verdadeiro ideal. Para ela, "não se trata de desenvolver uma educação específica para o contexto prisional, mas também não pode ser a mesma educação que os excluiu" (p.248). É preciso ter 
em vista e respeitar a diversidade do espaço prisional, buscando motivar as pessoas institucionalizadas a ver a educação como "uma possibilidade de emancipação ainda na condição de encarceradas" (p. 249). Nesse sentido, a autora salienta que "o maior desafio é implantar ações educativas significativas, uma vez que a instituição penal por um lado institucionaliza e retira a autonomia, e a educação, por outro lado, liberta e humaniza as pessoas" (p. 245).

De acordo com a professora Ariane, entre as diversas razões pelas quais a pessoa em privação de liberdade vai à escola está a busca por um espaço onde possa se expressar com mais liberdade. Segundo ela, muitas vezes, nem mesmo os próprios parceiros de cela mostram compreensão com o sofrimento emocional dos colegas. De acordo com a professora, se uma pessoa em privação de liberdade se queixa ou até mesmo chora no interior da cela, os colegas fazem chacotas ou se sentem incomodados com o clima desagradável, com os problemas que todos enfrentam em menor ou maior escala. Por esse ângulo, a escola se torna um refúgio, conforme o relato:

\begin{abstract}
"Muitas vezes, chego à sala de aula e um aluno diz para mim: 'Nossa, professora, preciso tanto conversar com a senhora'. 'Mas o que você precisa conversar?' 'Porque às vezes eu estou lá na cela, às vezes eu quero falar da minha trajetória aqui dentro, aí meus amigos acham que eu estou chorando cadeia, não é que eu estou chorando cadeia, é que tem hora que a gente tem necessidade de falar'. E eu falei: 'Então tá, vamos conversar'. Eu me sentei e ele foi falando, falou, falou, falou. Aí, eu disse: 'Você se sente melhor agora?'. Ele disse: 'Eu me sinto, eu precisava de alguém pra me ouvir, eu precisava ser ouvido, porque aqui a gente quase nunca é ouvido' (...) Muitos vão à escola para sair daquele ambiente rotineiro de cela. Eles falam assim, 'nossa, a gente fica na cela, as mesmas pessoas, os mesmos assuntos', então eles vão para a sala de aula porque veem em nós um elo entre eles e a sociedade, a gente acaba trazendo um pouco do contexto da sociedade lá fora para dentro da sala de aula. Então foge um pouco daquele ambiente da cela, daquelas pessoas que às vezes só falam de crime, coisas ruins, só coisas negativas. Na sala de aula é diferenciado, eles buscam esse espaço para ver outro universo, porque nós professores conversamos com eles coisas diferentes." (Ariane)
\end{abstract}

Interpreta-se que os professores em foco, por razões de adaptação à realidade do cenário carcerário e às necessidades de seus discentes, desenvolvem em seu perfil profissional habilidades de escuta e acolhimento emocional. Ao nosso ver, essas habilidades poderiam contribuir de maneira considerável na relação professoraluno das escolas regulares do Ensino Fundamental e Médio, que frequentemente não são marcadas por essa relação de apoio vista nessa escola de unidade prisional. O exercício da docência, pautada por uma relação de suporte emocional, pode ser o canal para uma maior simpatia do aluno em relação à figura do professor, potencializando o seu processo de aprendizagem, à medida que vai sendo psicologicamente reestruturado. Advoga-se que muitas vezes é importante que o professor ouça para poder ser ouvido, acolhendo a indisciplina dos alunos, não mais com o olhar de quem vê no caos da sala de aula o desrespeito generalizado, mas com o olhar profissional de quem percebe na sua indisciplina uma necessidade emocional de serem ouvidos e percebidos pelo outro.

A professora Antônia também fez referência a procedimentos de acolhimento e escuta emocional de seus alunos:

\begin{abstract}
"Eu os escuto, se eles têm algum problema 'professora, hoje eu não estou bem por causa disso, disso e disso...', lá eles reclamam muito da falta da família, que eles estão se sentindo sozinhos; têm dias que eles estão chorando demais, eu respeito aquele momento, não os obrigo 'você vai estudar', se está deitado na carteira eu deixo deitado, às vezes passa a aula inteira chorando, se quiser conversar eu também converso (...) eu dou muito conselho, eu entendo quando eles estão lá deitados na carteira, geralmente eu chego perto e pergunto o que está acontecendo, por que está desse jeito?: 'professora, hoje eu não estou bem', outra hora eles estão sentindo dor 'é muita dor, eu estou esperando para ir ao médico', em outros momentos estão preocupados por causa de audiência, ou por saudade da família.” (Antônia)
\end{abstract}

Quando arguida sobre os efeitos da intervenção dos professores sobre as demandas emocionais do aluno, a professora Ariane afirmou que frequentemente os alunos se tranquilizam e permitem novamente o fluir das aulas.

Os professores no interior das escolas de unidades prisionais são associados, pelas pessoas em privação de liberdade, com a imagem daqueles raros com os quais podem ser escutados sem julgamentos, acolhidos incondicionalmente e orientados com palavras pautadas no respeito e na dignidade humana. Ao que tudo indica, o professor é valorizado por seus alunos mais pelo que é enquanto pessoa do que pelo que é profissionalmente, ou seja, pelo apoio emocional que representa em um universo culturalmente repressor.

No sistema prisional, o professor é um profissional ligado à imagem de generosidade e compreensão, não no sentido de passividade a todos os desejos e demandas do aluno. Durante as entrevistas, ficou claro que os professores não são profissionais subordinados ao medo e tampouco à ansiedade que pessoas em privação de liberdade poderiam representar devido aos delitos aos quais cometeram; pelo contrário, os entrevistados 
deixaram claro o exercício de sua autoridade nas salas de aula. Fato é que a relação de escuta e acolhimento favorece a vinculação, o respeito e a disciplina do aluno. Uma vez que o professor ouve o aluno com atenção, muitas vezes até mesmo com certo carinho, instala-se um contrato, não dito, um compromisso emocional de consideração mútua com o qual o aluno simbolicamente tem em débito com o professor.

Bolívar (2006) sustenta que a autoimagem do professor tem estreitas vinculações com o "ser do aluno", destacando que, a partir de seu feedback, o professor não tem somente uma representação profissional (do presente) sobre si mesmo, como também frequentemente é motivado (in)conscientemente à projeção de sua autoimagem futura, apontada por ele como "identidade de projeto".

Vale destacar que os professores, ao falarem de sua experiência, especificamente aconselhando demandas emocionais, sugerem por meio de inúmeras expressões a identificação com um sentimento intrínseco de "missionários", por desenvolverem um trabalho que a seu ver pode participar da transformação do aluno enquanto "ser".

A professora Antônia, a esse respeito, chegou a afirmar que, se não atuasse profissionalmente na escola da unidade prisional e surgisse uma oportunidade em que ela pudesse desenvolver um trabalho mesmo não remunerado, ela se colocaria como voluntária:

“Às vezes, eu falo lá em casa nessas épocas de festa: 'Eu estou sentindo falta de meus alunos'. Porque ali eu não os vejo como presos, para mim eles são alunos. Só que eles são diferenciados, então a gente sente falta. Eu gosto muito... Se eu estivesse trabalhando só aqui fora e surgisse uma oportunidade de eu fazer um trabalho lá dentro, mesmo que eu não ganhasse, eu iri.” (Antônia)

O professor Thiago acredita que a educação pode transformar a vida das pessoas em sua maneira de pensar, bem como em sua condição social. Relata que, assim como ele foi tocado pela educação e teve sua vida transformada, pode contribuir com a renovação das perspectivas das pessoas em privação de liberdade:

"O que mais me motiva é achar que eu posso realmente transformar a vida deles, eu acredito que assim como eu fui 'pescado' no Ensino Médio por uma professora de Português que me marcou muito, então eu falo para mim mesmo: 'Gente, eu posso contribuir um pouquinho com esses alunos'. O reconhecimento de que a educação transformou a vida deles faz com que a gente se sinta bem também. 'Nossa, eu fiz parte disso', acho que a gente consegue ver os resultados mais rápidos, ao contrário do que aqui fora. Você fica, vamos supor, de fevereiro até agora eu consigo ver aqui fora muito menos resultado do que eu vejo lá." (Thiago)
Percebe-se na fala do último professor que as dimensões de sua vida pessoal foram fundamentais no processo de construção de sua identidade profissional. Sivieri-Pereira (2008, p. 122) afirma que a escolha da profissão docente frequentemente começa muito antes de sua vida adulta e se respalda em sua história de vida e nos professores que tiveram no Ensino Fundamental ou Médio. A autora esclarece que "a história que cada um vive determina escolhas futuras, na medida em que vão formando conceitos, desejos, percepções e deixando marcas que vão contribuindo significativamente para a construção da composição pessoal e profissional do professor".

A professora Letícia, assim como Thiago, acredita que a educação pode contribuir para que os alunos em privação de liberdade "se tornem pessoas diferentes, novos cidadãos e com mais consciência" Para ela, a atuação profissional do professor é uma oportunidade que ele tem de contribuir com o "resgate" do aluno em relação às suas atuais condições sociais:

“(...) ali (na unidade prisional) é uma chance que nós professores temos de dar o nosso melhor para poder resgatar aqueles alunos, vamos supor que sejam 100 alunos, se resgatarmos dois, três, a gente já está no lucro. As pessoas de fora falam que não ressocializam, que ali não vai ressocializar ninguém, mas é uma maneira de podermos mostrar para eles (os presos) que eles podem ser diferentes. Aqueles que estão hoje na escola, a maioria deles a gente percebe que deseja alguma mudança. Eles deixam bem claro os seus interesses, e se é por uma remição 'da vida', eles não se omitem em nenhum momento. Mas tem muitos ali que a gente percebe que estão tendo realmente a oportunidade que não tiveram de estudar. Nós não vamos salvar todos, mas alguma coisa a gente tem de fazer." (Letícia)

Em entrevista, a professora Ariane chegou a afirmar, inclusive com certo teor de espiritualidade:
"Acho que todos os professores que trabalham lá não entraram por acaso. Eu não sei se é uma obra de Deus, sei lá, se é uma questão de perfil, mas eu acho que nós não estamos ali à toa, se a gente entrou ali eu acho que tínhamos que aprender algo ali, a gente tinha que vivenciar aquela realidade." (Ariane)

Nesse sentido, a análise dos dados revelou que os docentes entrevistados possuem uma autopercepção profissional de professores "conselheiros", com um valor intrínseco de "missionários", por desenvolverem um trabalho que participa da transformação do aluno enquanto "ser". Esses elementos conferem a sua identidade profissional um sentimento positivo de autoestima ao perceberem sua própria utilidade e importância para a 
constituição do outro. Nessa relação dialética, o aluno acolhido pelo professor em suas demandas emocionais revela por eles o seu reconhecimento, e, na gratidão do aluno, o professor reconhece o seu valor profissional.

Dando sequência às análises da presente temática, outro aspecto da identidade profissional dos professores entrevistados que se destacou diz respeito à representação e consequentemente à autopercepção dos professores como docentes "corajosos". A professora Antônia, durante os seus relatos, declarou que sentia na educação escolar para alunos em privação de liberdade um ato de coragem, no sentido literal da palavra, isto é, uma pessoa capaz de exercer um trabalho que geraria medo em um grande número de pessoas. Por diversas vezes, expressou durante o seu discurso que as pessoas a viam como uma professora corajosa devido ao fato de lecionar para alunos dos mais diversos perfis criminais.

Intui-se, por meio das análises dos dados, que tal elemento da identidade docente, a "coragem", também confere aos professores uma espécie de vaidade ou sentimento de status social por desenvolverem um trabalho audacioso e desafiante aos olhos de outras pessoas.

De acordo com os estudos de Bolívar (2006, p. 205, tradução dos autores), toda profissão, especificamente a docente, é parte da trajetória de constituição identitária profissional e pessoal, uma necessidade e/ou uma tendência intrínseca ao processo de individualização, isto é, de realização e diferenciação pessoal dos demais companheiros de profissão. Essa "necessidade imperiosa de satisfação pessoal", quando não encontrada no trabalho, frequentemente, assim como outros aspectos, pode conduzir o profissional a um processo de crise de identidade, conflitando-o com um sentimento de estagnação em relação a sua autoimagem.

Observam-se tais indicativos no discurso da professora Letícia. Segundo suas narrativas, quando ela anunciava que exercia docência em uma escola de unidade prisional, as pessoas ficavam "impactadas". Consequentemente, ela experimentava em sua identidade profissional a sensação de ser uma professora "diferente":

\footnotetext{
"Eu me sinto diferente porque as pessoas me olham e falam: 'Nossa, você está dando aula para presos, mas eles não têm direito a isso, não'. Tem pessoas que já levam para outro lado, mas é porque eles não conhecem, não sabem o verdadeiro trabalho que é feito ali. Mas eu acho que eles nos veem de uma forma diferente. As pessoas dizem: 'Nossa, mas por que ela escolheu trabalhar lá, é melhor do que trabalhar na rua?'. Eu costumo falar: 'Eu prefiro trabalhar lá do que aqui na rua', e é verdade. Esse diferente que eles imaginam, eles perguntam se tem que ter um perfil para trabalhar lá, eu falo 'tem que ter um perfil, porque você tem que ter uma estrutura, você tem que ter um comportamento próprio'." (Letícia)
}

Convém destacar que, ao se referir a si mesma como uma professora diferente, não afirmou com a expressão de quem se sentia discriminada, mas sim com a expressão de quem se sentia uma pessoa singularizada. É importante notar que, sendo uma pessoa profissionalmente diferenciada, por executar um trabalho relativamente para poucos, ocasiona o despertar da curiosidade e das interrogativas por parte das pessoas desprovidas de tal experiência "espantosa", conforme Antônia, "impactante", segundo Letícia, abrindo espaço para que o professor possa expressar o seu saber e as suas vivências a um grande número de ouvintes. Acerca de tais ouvintes, a professora Ariane relatou que seus alunos adolescentes da educação socialmente regular (livres) frequentemente perguntam a ela como é sua experiência profissional dentro da unidade prisional, conforme declara:
“(...) eles ficam superinteressados, me perguntam como é, se eles estudam normalmente igual a eles (os alunos livres), se eu dou matéria igual, entendeu? Eles acham superdiferente, eles ficam: 'Como assim, professora?'. Ficam curiosos para saber sobre os alunos em privação de liberdade: 'Eles respeitam a senhora, professora?'. Eu digo: 'Respeitam mais do que vocês'.” (Ariane)

Bolívar (2006) concebe a identidade como um processo pelo qual o indivíduo estabelece uma coerência entre os diferentes espaços de convívio com os quais se identifica e suas vivências no contato com outras pessoas. A organização dessas duas dimensões (espaço e experiência no espaço) forma na concepção do autor um todo biográfico (dinâmico e singular) que delineia os pilares da identidade.

Outro fato ostensivo, em um cenário onde a indisciplina dos alunos gera adoecimento nos professores, gira em torno da afirmativa de que nos presídios os professores não têm, como na educação socialmente regular, problemas com indisciplina. Pelo contrário, de acordo com os entrevistados, são muito respeitados e valorizados pelos alunos em privação de liberdade.

Isso leva a intuir que a docência nos presídios aguça o imaginário de quem não está diretamente inserido na realidade das sociedades dos cativos, dotando o professor de saberes e vivências singulares do mundo do cárcere. Outro exemplo disso foi quando a professora Letícia expôs curiosidades acerca da cultura e da linguagem das pessoas em privação de liberdade:

\footnotetext{
"Eles têm termos muito próprios. Leite, por exemplo, não se fala 'leite', se fala 'vaquinha'. O 'boi' é o banheiro. Uma vez, eu perguntei assim: 'O que tem a ver boi com banheiro?'. Então me responderam: 'Ah, professora, porque quando fica noite e a gente vai dormir, fica fazendo um barulho igual de boi, porque a água sobe e desce e faz um barulho parecendo que deu
} 
descarga, então fica borbulhando, por isso a gente deu o nome de boi'. Essa é a cultura deles, isso já é antigo. Às vezes, eu falo: 'Vocês já almoçaram?'. Aí eles falam: 'Não, professora, a alimentação não chegou ainda'. Aí eles falam direitinho. Porque a marmita eles chamam de "cascuda". Eles falam o nome das frutas direitinho, maçã é maçã, mas banana não é banana, é 'a fruta amarela'.” (Letícia)

Ariane afirmou convicta: "Eu trabalhei quatro anos no ensino regular aqui fora e há quatro anos eu trabalho lá dentro. Nesse período, ganhei experiência e aprendizado que escola nenhuma aqui fora me oportunizou". O que confirma, mais uma vez, a fecundidade da experiência docente em escolas de unidades prisionais.

Nesse sentido, Bolívar (2006) afirma que a profissão ocupa espaço de destaque na vida dos indivíduos, conferindo-lhes aspectos de sua autoimagem, sobre aquilo que sabem e pelo reconhecimento de suas habilidades e competências. A identificação com o trabalho confere status e condições para a socialização. Sivieri-Pereira (2008) descreve que a constituição da autoimagem profissional docente apresenta-se como resultado entre as dimensões pessoais (biográficas) e o contexto social e institucional aos quais os docentes estão inseridos. No caso desta pesquisa, o contexto singulariza-se por se tratar de uma unidade prisional, regida por normas autárquicas. Os alunos, além de alunos, também são presos, e as salas de aula também se equiparam a celas.

\section{CONSIDERAÇÕES FINAIS}

A relação professor-aluno é, sem dúvida, o elemento marcante da profissão docente em espaços de privação e restrição de liberdade. É ao mesmo tempo a mola propulsora que motiva ao trabalho, a razão da realização profissional e o sentimento positivo de autoestima do professor. A qualidade dessa relação direciona o professor à decisão de permanecer ou não exercendo docência nesses espaços, fechando-se em uma cela de aula e privando-se de sua liberdade. Pelo aluno e pela satisfação ao trabalho, o professor enfrenta o descrédito social em relação à profissão docente em unidades prisionais, mantendo-se atuante anonimamente nesses espaços.

As especificidades dos alunos, assim como o retorno afetivo deles, convocam os professores ao desenvolvimento de habilidades específicas para atender às necessidades, não somente didáticas, de seus alunos. $\mathrm{E}$, ao se perceberem úteis, perante o retorno afetivo dos alunos, compreendem a importância de seu trabalho, sentindo-se realizados, Ao constatarem o valor de sua atuação profissional, assimilam também uma autoimagem positiva em relação a si mesmos.
Com suas demandas, carências e labilidades, o aluno leva o professor a construir uma identidade própria e uma autovisão positiva em relação ao seu trabalho. O espaço e a confiança que ele abre para o professor orientá-lo em sua vida particular conferem a esse profissional a autopercepção de seu papel de "conselheiro". Além disso, o sucesso escolar e as mudanças observadas nos valores dos alunos fazem com que o professor reconheça sua importância social e espiritual enquanto "missionário". Também sugerem nutrir a autoimagem de "corajoso" ou "audacioso" perante o imaginário social, que tende a acreditar que a docência em espaços de privação e restrição de liberdade seja uma profissão arriscada.

Advoga-se nesta pesquisa que o sentimento de realização profissional, a autoestima e a maneira pela qual o professor percebe a sua autoimagem (para si e para o outro) são elementos fundamentais para a interpretação e compreensão da identidade docente. Ressaltando que essa identidade e os elementos mencionados,são em grande medida influenciados pela relação professor-aluno.

Espera-se, sinceramente, que esta pesquisa venha contribuir para a diluição de preconceitos e ideias preconcebidas em relação à docência em espaços de privação e restrição de liberdade.

\section{REFERÊNCIAS}

BOLÍVAR, Antonio. La identidad profesional del profesorado de secundaria: crisis y reconstrucción. 5. ed. Málaga, Espanha: Ediciones Aljibe, 2006.

BRASIL. Código Penal. Brasília, 1984. Disponível em: <http:// www.planalto.gov.br/ccivil_03/decreto-lei/Del2848compilado. htm>. Acesso em: 27 jun. 2018.

BRASIL. Constituição da República Federativa do Brasil. Brasília, 1988. Disponível em: <http://www.planalto.gov.br/ ccivil 03/constituicao/constituicaocompilado.htm>. Acesso em: $2 \overline{7}$ jun. 2018.

CIAMPA, Antonio da Costa. Identidade. In: CODO, Wanderley; LANE, Silvia Tatiana Maurer (Org.). Psicologia social: o homem em movimento. São Paulo: Brasiliense, 1997.

DUARTE, Alisson José Oliveira. Processo de constituição da identidade profissional de professores da educação escolar de uma unidade prisional de Minas Gerais. 2017. $149 \mathrm{f}$. Dissertação (Mestrado em Educação) - Universidade Federal do Triângulo Mineiro (UFTM), Uberaba, 2017.

DUARTE, Alisson José Oliveira; SIVIERI-PEREIRA, Helena de Ornellas. Aspectos históricos da educação escolar nas instituições prisionais brasileiras do período imperial ao século XXI. Educação Unisinos, v. 22, n. 4, maio/jun. 2018.

OLIVEIRA, Carolina Bessa Ferreira. A educação escolar nas prisões: uma análise a partir das representações dos presos da penitenciária de Uberlândia (MG). Educ. Pesq., São Paulo, v. 39, n. 4, p. 955-967, out./dez. 2013.

ONOFRE, Elenice Maria Cammarosano. A escola da prisão como espaço de dupla inclusão: no contexto e para além das grades. Polyphonía, v. 22, n. 1, p. 111-120, jan./jun. 2011. 
ONOFRE, Elenice Maria Cammarosano. Desafio histórico da educação prisional brasileira: Ressignificando a formação de professores... um quê de utopia? Revista HISTEDBR On-Line, Campinas, n. 47, p. 205-219, set. 2012.

ONOFRE, Elenice Maria Cammarosano. Educação escolar para jovens e adultos em situação de privação de liberdade. Cad. Cedes, Campinas, v. 35, n. 986, p. 239-255, maio-ago. 2015.

ROGERS, Carl. Sobre o poder pessoal. 10. ed. São Paulo, Martins Fontes, 2001.

SIVIERI-PEREIRA, Helena de Ornellas. O professor principiante e os espaços de interação entre as dimensões pessoais e profissionais da carreira docente. 2008. $320 \mathrm{f}$. Tese (Doutorado em Ciências, Área: Psicologia) - Faculdade de Filosofia, Ciências e Letras, Universidade de São Paulo, Ribeirão Preto, SP, 2008.

VASQUEZ, Eliane Leal. Sociedade cativa. Entre cultura escolar e cultura prisional: uma incursão pela ciência penitenciária. 2008. 163 f. Dissertação (Mestrado em História da Ciência) - Pontifícia Universidade Católica, São Paulo, 2008.

Recebido em 13.05.2017.

Aprovado em 12.06.2018

Endereço para correspondência: Alisson José Oliveira Duarte Rua Iguatama - Jardim América 38036-140 Uberaba, MG, Brasil 